\title{
Legionella spp. in dental unit waterlines
}

\author{
Sedlata Juraskova $\mathrm{E}^{1}$, Sedlackova $\mathrm{H}^{2}$, Janska $\mathrm{J}^{1}$, Holy $\mathrm{O}^{3}$, Lalova $\mathrm{I}^{3}$, Matouskova $\mathrm{I}^{3}$ \\ Institute of Dentistry and Oral Sciences, Faculty of Medicine and Dentistry, Palacky University \\ Olomouc and University Hospital Olomouc, Czech Republic. ejuraskova@seznam.cz
}

\begin{abstract}
OBJECTIVE: To determine the current presence of Legionella spp. in the output water of dental unit waterlines (DUWLs) and examine its mitigation by disinfection at the Institute of Dentistry and Oral Sciences, Faculty of Medicine and Dentistry, Palacky University Olomouc and University Hospital Olomouc.

MATERIAL AND METHODS: The first stage of our survey involved collecting samples of DUWL output water from 50 dental chair units (DCUs), and 2 samples of the incoming potable water. In October 2015, a one-time disinfection ( $1 \%$ Stabimed) of DUWLs was conducted. This was followed by collecting 10 control samples (survey stage 2).

RESULTS: From the total of 50 samples (survey stage 1), 18 samples (36.0 \%) tested positive for Legionella spp. Following the disinfection, nine of the ten samples no longer showed any presence of Legionella.

CONCLUSION: Based on culture results, the one-time disinfection (1\% Stabimed) was effective. We are unable to comment on the duration of positive effect of disinfection on the occurrence of Legionella spp. in the outlet water. It was a one-time survey (Tab. 2, Ref. 32). Text in PDF www.elis.sk.

KEY WORDS: Legionella spp., water of dental unit waterlines, disinfection.
\end{abstract}

\section{Introduction}

The issue of microbial water contamination and biofilm formation in dental unit waterlines (DUWLs) has been discussed since the moment the first dental chair units (DCUs) were built. The first researcher to report the microbial contamination of DUWL output water was Blake in 1963 (1). This was followed by numerous studies describing both mechanical (rinsing, filtration) and chemical (sodium hypochlorite, chlorhexidine gluconate, hydrogen peroxide) elimination of microorganisms or biofilm in DUWL water (2, $3,4,5)$. It was also pointed out that the use of selected biocides (sodium hypochlorite, glutaraldehyde, isopropanol) may lead to the accumulation of these substances in biofilm matrix and their uncontrolled release. The authors consider this fact an additional risk for patients (6). Risk factors responsible for the contamination of DUWL water include the microbiological, biological, physical, and chemical indicators of the incoming water. Some of the most

${ }^{1}$ Institute of Dentistry and Oral Sciences, Faculty of Medicine and Dentistry, Palacky University Olomouc and University Hospital Olomouc, Czech Republic, ${ }^{2}$ Public Health Institute Ostrava, Centre of Hygienic Laboratories, Olomouc branch, Czech Republic, and ${ }^{3}$ Department of Preventive Medicine, Faculty of Medicine and Dentistry, Palacky University Olomouc, Czech Republic

Address for correspondence: E. Sedlata Juraskova, MD, PhD, Institute of Dentistry and Oral Sciences, Faculty of Medicine and Dentistry, Palacky University Olomouc and University Hospital Olomouc, Czech Republic, Palackeho 12, CZ-772 00 Olomouc, Czech Republic. Phone: +420777554728

Acknowledgement: Grand support - Studentská grantová soutěž Univerzity Palackého 2015 - IGA LF 2015005. important factors deciding the microbial contamination or quality of water include a very small lumen size $(0.5-2 \mathrm{~mm})$, extremely long distribution tubing (up to $10 \mathrm{~m}$ ), frequent irregular stagnation of the incoming water, and biofilm formation. Microorganisms found in such environments are conditionally pathogenic bacteria, microscopic filamentous fungi, and various protozoa essential to the survival of Legionella $(7,8,9)$. Therefore, it is necessary to establish the microbial diversity of microorganisms in the incoming water, and accordingly select the best biocides $(10,11)$. The effectiveness of biocides is tested under laboratory conditions as well as in dental office $(12,13)$. Tuttlebee and his team tested two peroxide-based biocides and found that Sanosil was more suitable for repeated DUWL decontamination (14). A multicenter study held in seven EU countries yielded highly interesting results concerning the microbial contamination of DUWL water. Only $49 \%$ samples of the DUWL output water complied with the recommendations of the American Dental Association (ADA), i.e. < $200 \mathrm{cfu} / \mathrm{ml}$. The tests showed Legionella pneumophila sg. 1 to be rare (15). A similar study was conducted in 2006, aimed at establishing the effects of eight biocides on reducing the biofilm and planktonic microorganisms. The tests confirmed that continuous application of biocides produces better results compared with occasional applications. The most effective biocides were Dentosept $\mathrm{P}$ and Oxygenal 6.

In general, microorganisms living in the output water enter the dental office in form of water droplets of varied size as "bioaerosol", which poses a risk of cross-transmission of infectious agent to patients and medical staff. The risks of dental bioaerosol containing Legionella is highlighted by Szymaňska (10). To date, only one terminal case of Legionnaire's disease acquired in con- 
nection with dental treatment (a female patient aged 82 years) has been documented (16).

Even such a comprehensive publication as "Legionella and the Prevention of Legionellosis" dedicates not more than a few lines to the DCU water system (17). After 12 years, the Centers for Disease Control and Prevention (CDC) revised and updated its guidelines aimed at preventing nosocomial infections and infection control in dental health-care settings,. The guidelines have largely remained the same, recommending again regular quantitative monitoring of microorganisms in DUWLs and preserving the bacteria limit at $<500 \mathrm{cfu} / \mathrm{ml}$ of water (18). The ADA set a limit of $<200 \mathrm{cfu} / \mathrm{ml}$ for water used in dental operations. Another recommendation suggested qualitative testing of DUWL water for Legionella $(18,19)$.

The present descriptive cross-sectional study was designed to establish the current incidence or absence of Legionella bacteria in the DUWL water at the Institute of Dentistry and Oral Sciences, Faculty of Medicine and Dentistry, Palacky University Olomouc and University Hospital Olomouc.

Its findings are discussed on the basis of data from available literature, in particular those dealing with the concern that output water contaminated with Legionella poses a risk to patients and medical staff.

\section{Material and methods}

In the first stage of our survey, held in the second half of 2015, a total of 50 samples of DUWL output water were collected, together with 2 samples of potable water supplied to the entire clinic. The clinic receives water from a single supply of potable water from the Olomouc water distribution system. The sampler used in our survey was a 50-ml disposable sterile plastic conical vial with a screw cap (DispoLab). Prior to sampling, the incoming water distributed from the clinic's water system was left to run for 5 minutes. Water entering the DUWLs was declared to be potable. The prosthetic, preservative, periodontal, and paediatric-dental departments were all equipped with the KaVo Systematica 1060 DCUs, and the Department of Conservative Dentistry had one more type of the DCU (one set) in use, namely Diplomat DM 10 Chirana. In the case of the Diplomat, a sample of distilled water from a built-in reservoir was collected. The orthodontic department was equipped with the KaVo ORTHOcenter 1058 O orthodontic DCUs.
The DUWL output water was sampled from a total of three points: micromotor supply tube, turbine hand piece quick coupler supply tube, and water/air blow gun supply tube. This output water was left to run for 5 minutes prior to sampling. In October 2015, the waterlines of 10 DCUs were disinfected with $1 \%$ Stabimed solution. This concentration requires a 30-minute exposure, and has bactericidal, fungicidal, mycobactericidal, tuberculocidal, and virucidal effects. The active substance is cocopropylendiamine (20). This particular method of DUWL disinfection was recommended by a service technician. After the exposure time had elapsed, the DUWLs were rinsed with potable water for 15 minutes. Prior to testing, the output water was left to run from the sampling site for the duration of 5 minutes.

Ten DCUs were selected for the DUWL disinfection. Of these, eight tested positive for Legionella sp. and two tested negative for Legionella sp. in their output water in Stage 1. Control sampling of output water (survey stage 2) was carried out on the same days as the disinfection, following the same procedure as described above.

Immediately after collection, the samples of output water were delivered at temperatures less than $18^{\circ} \mathrm{C}$ to the Testing Laboratory No. 1393, accredited by the Czech Accreditation Institute according to CSN EN ISO/IEC 17025, of the Public Health Institute Ostrava, Centre of Hygienic Laboratories, Olomouc branch, for processing.

The Legionella strain was culture-confirmed using method under SOP OV 913 (specification ČSN ISO 11731, ČSN ISO11731-2). Colonies of presumptive Legionella organisms were confirmed by serotyping. In one case, Legionella was determined with the help of molecular biological typing at the Ostrava Health Institute, Department of Molecular Biology (Legionella quateirensis).

Note: The confirmed estimated number of Legionella bacteria is specified as cfu (colony forming units) of Legionella species per $100 \mathrm{ml}$ of water sample.

\section{Results}

From the total of 50 samples of output water (survey stage 1), 18 samples (36.0\%) tested positive for Legionella bacteria, whose quantity was specified as $\mathrm{cfu} / 100 \mathrm{ml}$ of sample. The tests confirmed the presence of $L$. pneumophila and presumptive presence of other Legionella species. Serotyping identified the following species:

Tab. 1. Microbial contamination of dental unit waterlines (survey stage 1).

\begin{tabular}{|c|c|c|c|c|c|c|}
\hline & \multicolumn{6}{|c|}{ Department and number of dental units (n) } \\
\hline & $\begin{array}{c}\text { Conservative dentistry } \\
n=11\end{array}$ & $\begin{array}{c}\text { Prosthetic } \\
n=12\end{array}$ & $\begin{array}{c}\text { Periodontology } \\
n=7\end{array}$ & $\begin{array}{l}\text { Pediatric dentistry } \\
n=10\end{array}$ & $\begin{array}{c}\text { Orthodontic } \\
n=10\end{array}$ & $\begin{array}{l}\text { Total } \\
n=50\end{array}$ \\
\hline Positive samples (\%) & $4(36 \%)$ & $6(50 \%)$ & $4(57 \%)$ & $4(40 \%)$ & $0 \%$ & $18(36 \%)$ \\
\hline Range (cfu/100ml) & $2.8 \times 10^{3-} 2.9 \times 10^{5}$ & $10-6.6 \times 10^{3}$ & $60-5.8 \times 10^{3}$ & $10-7.5 \times 10^{4}$ & 0 & $10-2.9 \times 10^{5}$ \\
\hline $\begin{array}{l}\text { L. pneumophila sg. } 4 \\
\text { Positive samples (\%) }\end{array}$ & $4(100 \%)$ & $2(33 \%)$ & $4(100 \%)$ & $4(100 \%)$ & - & $14(78 \%)$ \\
\hline $\begin{array}{l}\text { L. anisa } \\
\text { Positive samples (\%) }\end{array}$ & - & $3(50 \%)$ & $1(25 \%)$ & - & - & $4(22 \%)$ \\
\hline $\begin{array}{l}\text { L. quateirensis } \\
\text { Positive samples (\%) }\end{array}$ & $1(25 \%)$ & $4(67 \%)$ & $2(50 \%)$ & - & - & $7(39 \%)$ \\
\hline
\end{tabular}


Tab. 2. Qualitative and quantitative changes after disinfection of DUWLs.

\begin{tabular}{|c|c|c|c|c|}
\hline Department & $\begin{array}{l}\text { Samples before disinfection } \\
(\mathrm{cfu} / 100 \mathrm{ml})\end{array}$ & Microbiological indicator & $\begin{array}{l}\text { Samples after disinfection } \\
(\mathrm{cfu} / 100 \mathrm{ml})\end{array}$ & Microbiological indicator \\
\hline \multirow{3}{*}{ Conservative dentistry } & $3.4 \times 10^{3}$ & $\begin{array}{l}\text { L. pneumophila sg. } 4 \\
\text { L.quateirensis }\end{array}$ & 0 & - \\
\hline & 0 & - & 0 & - \\
\hline & $2.8 \times 10^{3}$ & L. pneumophila sg. 4 & 0 & - \\
\hline \multirow[b]{2}{*}{ Prosthetic } & 10 & L. pneumophila sg. 4 & 0 & - \\
\hline & $3.6 \times 10^{3}$ & $\begin{array}{l}\text { L. pneumophila sg. } 4 \\
\text { L. anisa }\end{array}$ & 0 & - \\
\hline \multirow{2}{*}{ Periodontology } & $1.8 \times 10^{3}$ & $\begin{array}{l}\text { L. pneumophila sg. } 4 \\
\text { L.quateirensis }\end{array}$ & 0 & - \\
\hline & $8 \times 10^{2}$ & $\begin{array}{c}\text { L. pneumophila sg. } 4 \\
\text { L. anisa } \\
\text { L.quateirensis }\end{array}$ & $4 \times 10^{2}$ & L. pneumophila sg. 4 \\
\hline \multirow{3}{*}{ Pediatric dentistry } & $7.5 \times 10^{4}$ & L. pneumophila sg. 4 & 0 & - \\
\hline & $1.4 \times 10^{3}$ & L. pneumophila sg. 4 & 0 & - \\
\hline & 0 & - & 0 & - \\
\hline Orthodontic & 0 & - & 0 & - \\
\hline
\end{tabular}

cfu - colony forming units

Legionella pneumophila sg. 4 alone or mixed with other Legionella species was found in 14 (i.e. $77.78 \%$ ) of the total 18 positive samples of the output water.

Legionella anisa (4 samples, all mixed with another Legionella species)

Legionella quateirensis (8 samples, of which 6 were mixed with another Legionella species).

All 10 samples of output water in the orthodontic offices were culture-negative, free of any Legionella.

The two samples of the incoming potable water were culturenegative; no Legionella was detected. Table 1 shows the number of the output water samples collected at the clinic's departments and the results of the determination of Legionella bacteria (presence/absence) in Stage 1 of the survey.

In October 2015, the waterlines of 10 DCUs were disinfected with $1 \%$ Stabimed solution. Of the eight samples of DCU output water that had been previously found to contain Legionella, seven tested negative for Legionella after disinfection. The eighth sample of output water, which showed the presence of Legionella in Stage 1 remained positive even after disinfection. The sample, however, underwent both qualitative and quantitative changes. Two samples of DCU output water that were found free of Legionella in Stage 1 of the survey, yielded the same results in Stage 2 of the survey.

\section{Discussion}

DUWLs are regularly contaminated with microorganisms ranging from $10^{2}$ to $10^{8} \mathrm{cfu} / \mathrm{ml}$ of output water. The first mention of L. pneumophila sg. 1 in the DCU output water dates to 1986, Germany, where water from 42 dental units was surveyed and Legionella was identified in four of the units (21). The Czech Republic dental chair units are required to be connected to potable water mains. Its quality needs to conform to current legis- lation (22). During dental procedures, dentists need a considerable amount of water. As scientists have long established the fact that output water is microbially contaminated to varied levels, dentists are recommended to use sterile water for surgical procedures (18). Microbial contamination of DUWL water occurs as a result of three vehicles: microbial quality of incoming water, bacteria present in the biological material of the treated patient (back flow), and proliferation of all these microorganisms, which may produce a biofilm on the DUWL's inside wall. Potable water is not sterile and contains planktonic aerobic Gram-negative and non-fermenting bacteria. Most of these organisms are nonpathogenic or conditionally pathogenic. The most accurate current information on the composition and dynamics of DUWL bacterial community was published by Costa et al. They worked with pyrosequencing data to identify changes in the DUWL bacterial community, and included Legionella spp. and Pseudomonas spp. among potential human pathogens. These two genera were detected both in the incoming water and output water following water stagnation, and subsequently in output water following the application of rotary instruments. The authors conclude that microbes in this community may infect patients or medical staff at any point of time and harm their health. These microbes are small droplets in an infectious bioaerosol, which develops during dental treatment $(23,24)$.

Our study aimed solely at detecting Legionella in DUWLs. From the total of 50 samples of output water (survey stage 1), 18 samples (36.0 \%) tested positive for Legionella organisms, whose quantity was specified as CFU/100 $\mathrm{ml}$ of sample. Serotyping identified the following species: Legionella pneumophila sg. 4, Legionella anisa and Legionella quateirensis. The prevalence of microbial contamination of CDUs is established to be $36.0 \%$ which corresponds to the values of contaminated DCUs reported by Szymaňska in her review (10-78 \%). Likewise, quantitative values such as $\mathrm{cfu} / 100 \mathrm{ml}$ of output water correspond to the data 
reported by Szymaňska based on multiple sources. The range of quantitative values established in our study appears near the bottom limits of the mentioned figures (10).

The first case of an infection caused by Legionella pneumophila sg. 4 was reported in 1978 in Los Angeles (25). Another case of an infection caused by L. pneumophila sg. 4 was also described in Los Angeles. This Legionella species was cultured from the articular tissue of a woman aged 80 years. The majority of extrapulmonary infections are associated with direct inoculation of the microorganism into a wound site during bathing or upon contact with contaminated water (26). In general, extrapulmonary Legionella infections are more prevalent in immunocompromised patients and patients with rheumatoid arthritis (27).

Legionella anisa was described as a new Legionella species by Gorman and his team (CDC, Atlanta) from potable water collected in hospitals in Chicago and Los Angeles during an outbreak of hospital-acquired Legionnaires' disease, and from cooling tower water (28). Bornstein and his team in France were the first to isolate this Legionella species from clinical material, particularly pleural fluid of a young man who had had two cytotoxic chemotherapy regimens (29). Legionella anisa currently ranks among non-L. pneumophila spp. that pose a threat to immunosuppressed patients. In 2003, Yamamoto and his team isolated L. anisa from multiple sites of a hospital water system, including shower heads in an obstetrics ward. This marked the first isolation of L. anisa in a hospital (30). As his Legionella species is more often isolated from environment than from clinical material, it is less pathogenic for humans compared with L. pneumophila. However, the authors stress the fact that L. anisa may cause infection in immunocompromised patients (31).

Legionella quateirensis was isolated as a separate Legionella species from water and was described on the basis of serological and biochemical properties of colonies cultured on buffered charcoal-yeast extract agar (BCYE) in 1993 (32).

\section{Conclusions}

Water quality was tested according to the above-mentioned SOP. The prevalence of microbially contaminated DCUs established in our study, namely $36.0 \%$, corresponds to the values of contaminated DCUs reported in foreign literature. The effectiveness of one-time disinfection was proven by the absence of Legionella and by quantitative and qualitative changes that took place in one sample of the output water. We are unable to comment on the duration of effects of the biocide used. We believe that based on foreign literature data on DUWL microbial contamination, regular decontamination of DCUs should be included in the operating rules of dental offices, and above all, carried out.

\section{References}

1. Blake GC. The incidence and control of bacterial infection of dental unit and ultrasonic scales. Br Dent J 1963; 15:413-416.

2. McEntegart MG, Clark A. Colonisation of dental units by water bacteria. Br Dent J 1973; 134 (4): 140-142.
3. Santiago JI, Huntington MK, Johnston AM, QuinnRS, Williams JF. Microbial contamination of dental unit waterlines: short-and long-term effects of flushing. Gen Dent 1994; 48 (6): 528-535.

4. Barbeau J, Tanguay R, Faucher $\mathbf{E}$ et al. Multiparametric analysis of waterline contamination in dental units. Appl Environ Microbiol 1996; 62 (11): 3954-3959.

5. Murdoch-Kinch CA, Andrews NL, Atwan S, Jude RGleason MJ, Molinari JA. Comparison of dental water quality management procedures. J Am Dent Assoc 1997; 128 (9): 1235-1243.

6. Meiller TF, Depaola LG, Kelley JI, Baqui AA, Turng BF, Falkler WA. Dental unit waterlines: biofilms, disinfectio and recurrence. J Am Dent Assoc 1999; 130 (1): 65-72.

7. Pasquarella C, Veronesi L, Castiglia P, Liguori G, Montagna MT, Napoli Ch et al. Italian multicentre study on microbial environmental contamination in dental clinics: a pilot study. Sci Total Environ 2010; 408: 4045-4051.

8. Pasquarella C, Veronesi L, Napoli Ch, Castiglia P, Liguori G, Rizzetto $\mathbf{R}$ et al. Microbial environmental contamination in Italia dental clinics: A multicenter study yielding recommendations for standardized sampling methods and threshold values. Sci Total Environ 2012; doi:10.1016/j.scitotenv.2012.01.030.

9. O'Donnell MJ, Boyle MA, Russell R, Coleman DC. Management of dental unit waterline biofilms in the 21st century. Future Microbiol 2011; 6 (10): 1209-1226.

10. Szymaňska J. Risk of exposure to Legionella in dental practice. Ann Agric Environ Med 2004; 11: 9-12.

11. Szymaňska J, Sitkowska J. Bacterial contamination of dental unit waterlines. Environ Monit Assess 2013; 185: 3603-3611.

12. Tachikawa M, Yamanaka K. Synergistic disinfection and removal of biofilm by a sequential two-step treatment with ozone followedby hydrogen peroxide. Water Research 2014; 64: 94-101.

13. Wang H, Pryor MA, Edwards MA, Falkinham JO, Pruden A. Effect of GAC pre-treatment and disinfectant on microbial community structure and opportunistic pothogen occurrence. Water Research 2013; 47: 5760-5772.

14. Tuttlebee CM, O'Donnell MJ, Keane CT, Russell RJ, Sullivan DJ, Falkiner $\mathbf{F}$ et al. Effective control of dental chair unit waterline biofilm and marked reduction of bacterial contamination of output water using two peroxide-based disinfectants. J Hosp Infect 2002; 52: 192-205.

15. Walker JT, Bradshaw DJ, Finney M, Fulford MR, Frandsen E, Ostergaard E et al. Microbial evaluation of dental unit water systems in general dental practice in Europe. Eur J Oral Sci 2004; 112: 412-418.

16. Ricci ML, Fontana S, Pinci F, et al. Pneumonia associated with dental unit waterline. Lancet 2012; 379 (18): 684.

17. Ed. Bartram J, Chartier Y, Lee JV et al. Legionella and the prevention of legionellosis. WHO 2007, 137 pp.

18. Fluent MT, Pawloski CL. CDC Infection Control in Dental HealthCare Settings: Looking Ahead to 2015, 1-12.

19. Centers for Disease Control. Guidelines for infection-control in dental health-care settings 2003. MMWR Morb Mortal Wkly Rep, 2003; 52 (RR-17): 1-76.

\section{0. http://braunoviny.bbraun.cz}

21. Reinthaler F, Mascher F. Demostration of Legionella pneumophila in dental units. Zentralbl Bakteriol Mikrobiol Hyg B 1986; 183 (1): 86/8. 
310-314

22. Vyhláška č. 252/2004 Sb., kterou se stanoví hygienické požadavky na pitnou a teplou vodu a četnost a rozsah kontroly pitné vody v platném znění.

23. Costa D, Mercier A, Gravouil K, Lesobre J, Delafont V, Bousseau A et al. Pyrosequencing analysis of bacterial diversity in dental unit waterlines. Water Research 2015; 81: 223-231.

24. Costa D, Girardot M, Bertaux J, Verdon J. Efficacy of dental unit waterlines disinfectants on a polymicrobial biofilm. Water Res 2016; 91: $38-44$.

25. Edelstein PH, Meyer RD, Finegold SM. Isolation of a new serotype of legionnaires'disease bacterium. Lancet 1978: 1172-1174.

26. LowryPW, Blankenship RJ, Gridley W et al. A cluster of Legionella sternal woud infections due to postoperativetopicalexposureto contaminatedtap water. N Engl J Med 1991; 324: 109-113.

27. Chang CC, Chung CL, Huang CL et al. Legionnaires' disease in a patient with rheumatoid arthritis. J Microbiol Immunol Infect 2001; 34 : $76-78$.
28. Gorman GW, Feeley JC, Steigerwalt A et al. Legionella anisa: a New Species of Legionella Isolated from Potable Waters and a Cooling Towe. Appl Environ Microbiol 1985; 49 (2): 305-309.

29. Bornstein N, Mercatello A, Marmet D. et al. Pleural Infection Caused by Legionella anisa. J Clin Microbiol 1989; 27 (9): 2100-2101.

30. Yamamoto N, Kubota T, Tateyama M et al. Isolation of Legionella anisa from multiple sites of a hospital water system: the eradication of Legionella contamination. J Infect Chemother 2003; 9 (2): 122-125.

31. Muder RR, Yu VL. Infection due toLegionella species other than L. pneumophila. Clin Invest Dis 2002; 35: 990-998.

32. Dennis PJ, Brenner DJ, Thacker WL et al. Five new Legionella species isolated from water. Int J Syst Bacteriol 1993; 43 (2): 329-337.

Received January 12, 2017. Accepted January 28, 2017. 